\title{
Hodgkin disease of thymic origin
}

\author{
Antonio Ríos Zambudio, MD, Juan Torres Lanzas, PhD, Pedro José Galindo Fernández, MD, \\ María José Roca Calvo, PhD, and Pascual Parrilla Paricio, PhD, Murcia, Spain
}

$\mathrm{T}$ he thymus is a principally lymphoid organ located in the anterosuperior mediastinum and one of the main elements of the immune system. Thymic disease is generally uncommon, and it can be quite varied. The most common thymic tumors are thymomas, but other types of tumors are located in the thymus, and making a differential diagnosis is important because treatment varies greatly from one type of disease to another. ${ }^{1}$

The fact that the thymus is a lymphoid organ makes it a site for lymphomatous tumor, although primary lymphomas of the thymus are uncommon. ${ }^{1}$ These lesions make up a heterogeneous group of lymphoproliferative neoplasms, and the distinction between Hodgkin disease and non-Hodgkin lymphoma must be made. Thymic lymphomas must always be considered among the diagnostic options, because the prognosis is strongly dependent on correct early treatment.

We report 4 cases of Hodgkin disease of thymic origin and review the literature.

\section{Clinical Summary}

The patients were less than 40 years old (26-39 years), and 3 patients were women. The time between the onset of symptoms and consultation was 1 to 3 months, the initial symptom being coughing in 2 patients and dyspnea in another. The fourth patient was asymptomatic, with only cervical adenopathies on physical exploration (Table 1).

Simple chest radiography showed an anterosuperior mediastinal tumor in all cases. Thoracic computed tomography (CT) revealed a solid heterogeneous thymic tumor. One of the patients had a pericardial effusion, and another had mediastinal adenopathies. Nuclear magnetic resonance (NMR) imaging was done in the patient with pericardial effusion and showed a thymic tumor without infiltration of neighboring structures and with associated pericardial effusion. A lymph node biopsy was obtained in the patient with cervical adenopathies; the anatomopathologic study was negative for lymphoma. Fine-needle aspiration of the mediastinal tumor was performed in 2 of the patients. In 1 patient it suggested thymoma, and in the other it was negative for tumor cells. The initial diagnostic suspicion was thymoma in all patients;

From the Department of General and Thoracic Surgery, Virgen de la Arrixaca University Hospital, Murcia, Spain.

Received for publication Oct 10, 2001; accepted for publication Dec 10, 2001.

Address for reprints: Antonio Rios Zambudio, MD, Avenida de la Libertad No. 208, Casillas, 30007, Murcia, Spain (E-mail: ARZRIOS@teleline.es).

J Thorac Cardiovasc Surg 2002;123:1208-10

Copyright $\odot 2002$ by The American Association for Thoracic Surgery

$0022-5223 / 2002 \$ 35.00+0 \quad \mathbf{1 2 / 5 4 / 1 2 2 1 1 3}$

doi: $10.1067 / \mathrm{mtc} .2002 .122113$ in 2 a differential diagnosis with lymphoma was considered, because of the presence of peripheral adenopathies in one and because of the mediastinal adenopathies found in the CT scan in the other.

All the patients underwent a surgical procedure and all had an intraoperative biopsy of the thymic tumor -2 because of a preoperative suspicion of lymphoma and the other 2 because of intraoperative suspicion of the same. The histologic study revealed lymphoma in 2 patients $(50 \%)$ and thymoma in the other $2(50 \%)$. Thymectomy was performed in the 2 patients with suspected thymoma, and only a biopsy was obtained in the 2 with lymphoma. During the postoperative period, complications developed in the the 2 patients having a thymectomy: a pulmonary thromboembolism necessitating anticoagulation, which evolved favorably, and a mediastinal hematoma, which required a blood transfusion ( 2 units of red corpuscle concentrate).

The definitive histologic study in all cases confirmed nodular sclerosis-type Hodgkin disease of thymic origin. Three cases were stage I and the fourth was stage II, according to the Cotswold classification. Treatment was with Mantle-type radiotherapy and chemotherapy in all cases. The chemotherapy was different in each case due to the fact that we applied the chemotherapeutic protocol for Hodgkin disease that was most accepted at the time of diagnosis.

Two patients are currently asymptomatic and disease-free 20 and 16 years after diagnosis. The third patient received treatment with 5 cycles of chemotherapy (ABVD; Adriamycin [doxorubicin], bleomycin, vinblastine, and dacarbazine) and radiotherapy; however, the persistence of a residual mediastinal mass was noted, with uptake in gammagraphy with gallium 67 and positron emission tomography, and further cycles of chemotherapy (C-MOPP; cyclophosphamide, mechlorethamine, Oncovin [vincristine], procarbazine, and prednisone) were administered. Currently, 1 year after diagnosis, the patient has active mediastinal disease despite treatment. The last patient, after 2 months' evolution, is being treated with radiotherapy and chemotherapy, pending assessment of the response to this therapy.

\section{Comment}

Hodgkin disease of thymic origin manifests itself in the second to third decades of life and more frequently in men; these characteristics differentiate it from systemic Hodgkin disease, which appears at two different ages (second to third decades and after the fifth decade of life) and is more common in women. ${ }^{1-4}$ Clinically, patients with Hodgkin disease of thymic origin are asymptomatic until extrathymic disease develops, which is generally when the diagnosis is made. As with any lymphoma, the presence of adenopathies is common. This was the case in 2 of our patients: one with cervical adenopathies and one with mediastinal adenopathies. ${ }^{1-3}$ On diagnosis, a third of the patients usually have fever, nocturnal sweating, weight loss, and other constitutional symp- 
TABLE 1. Our series of Hodgkin disease of thymic origin

\begin{tabular}{|c|c|c|c|c|}
\hline & Case 1 & Case 2 & Case 3 & Case 4 \\
\hline Sex & Female & Female & Female & Male \\
\hline Age & 26 y & 39 y & 35 y & 26 y \\
\hline Evolution time & $3 \mathrm{mo}$ & $2 \mathrm{mo}$ & $2 \mathrm{mo}$ & $1 \mathrm{mo}$ \\
\hline Onset & Irritating cough & Cervical adenopathy & Dyspnea & Irritating cough \\
\hline Other symptoms & $\begin{array}{l}\text { Weight loss, nocturnal } \\
\text { sweating }\end{array}$ & No & Chest tightness & Fever \\
\hline $\begin{array}{l}\text { Simple chest } \\
\text { radiography }\end{array}$ & $\begin{array}{l}\text { Anterosuperior mediastinal } \\
\text { tumor }\end{array}$ & $\begin{array}{l}\text { Anterosuperior mediastinal } \\
\text { tumor }\end{array}$ & $\begin{array}{l}\text { Anterosuperior mediastinal } \\
\text { tumor }\end{array}$ & $\begin{array}{l}\text { Anterosuperior } \\
\text { mediastinal tumor }\end{array}$ \\
\hline Chest CT & $\begin{array}{c}\text { Heterogeneous thymic tumor, } \\
\text { mediastinal adenopathies }\end{array}$ & $\begin{array}{l}\text { Heterogeneous thymic } \\
\text { tumor, no adenopathies }\end{array}$ & $\begin{array}{l}\text { Heterogeneous thymic } \\
\text { tumor, pericardial } \\
\text { effusion, no } \\
\text { adenopathies }\end{array}$ & $\begin{array}{l}\text { Heterogeneous thymic } \\
\text { tumor, no } \\
\text { adenopathies }\end{array}$ \\
\hline Chest NMR & No & No & $\begin{array}{l}\text { Thymic tumor not } \\
\text { infiltrating other } \\
\text { structures, pericardial } \\
\text { effusion, no } \\
\text { adenopathies }\end{array}$ & No \\
\hline $\begin{array}{l}\text { Lymph node } \\
\text { biopsy }\end{array}$ & No & Yes (negative) & No & No \\
\hline Thymic FNA & No & Yes (negative) & No & Yes (thymoma) \\
\hline $\begin{array}{l}\text { Diagnostic } \\
\text { suspicion }\end{array}$ & Lymphoma/thymoma & Lymphoma/thymoma & Thymoma & Thymoma \\
\hline Surgical approach & Mediastinotomy & Sternotomy & Sternotomy & Sternotomy \\
\hline Surgical findings & $\begin{array}{l}\text { Thymic tumor not affecting } \\
\text { adjacent structures, } \\
\text { mediastinal adenopathies }\end{array}$ & $\begin{array}{l}\text { Thymic tumor affecting } \\
\text { costal wall, pericardium, } \\
\text { and pleura }\end{array}$ & $\begin{array}{l}\text { Thymic tumor infiltrating } \\
\text { pleura }\end{array}$ & $\begin{array}{l}\text { Thymic tumor infiltrating } \\
\text { upper left pulmonary } \\
\text { lobe, mediastinal } \\
\text { adenopathies }\end{array}$ \\
\hline $\begin{array}{l}\text { Intraoperative } \\
\text { biopsy }\end{array}$ & Lymphoma (Hodgkin) & Fibrosis-thymoma & Thymoma & Lymphoma \\
\hline Surgical technique & Biopsy & Partial thymectomy & $\begin{array}{l}\text { Thymectomy, pericardial } \\
\text { window }\end{array}$ & Biopsy \\
\hline $\begin{array}{l}\text { Postoperative } \\
\text { complications }\end{array}$ & No & $\begin{array}{l}\text { Pulmonary } \\
\text { thromboembolism }\end{array}$ & Mediastinal hematoma & No \\
\hline $\begin{array}{l}\text { Hodgkin lymphoma } \\
\text { type }\end{array}$ & Nodular sclerosis & Nodular sclerosis & Nodular sclerosis & Nodular sclerosis \\
\hline Cotswold staging & IB & $\mathrm{IE}$ & IE & $\| A$ \\
\hline $\begin{array}{l}\text { Mantle-type } \\
\text { radiotherapy }\end{array}$ & 3950 rads & 3500 rads & 3500 rads & 3500 rads \\
\hline Chemotherapy & C-MOPP & C-MOPP & ABVD and C-MOPP & ABVD \\
\hline Evolution & Asymptomatic (20 y) & Asymptomatic (16 y) & Residual disease (1 y) & $-(2 \mathrm{mo})$ \\
\hline
\end{tabular}

$C T$, Computed tomography; NMR, nuclear magnetic resonance; FNA, fine-needle aspiration; $C$-MOPP, cyclophosphamide, vincristine, procarbazine, and prednisone; $A B V D$, Adriamycin (doxorubicin), bleomycin, vincristine, and dacarbazine.

toms ${ }^{1}$ chest symptoms being uncommon. However, in some cases compression or invasion of mediastinal structures may trigger symptoms such as chest pain, coughing, or dyspnea. ${ }^{1}$

Nearly $100 \%$ of the patients have radiologic evidence of intrathoracic disease in the form of an anterior mediastinal narrowing, as was true in our patients. CT shows a solid heterogeneous thymic mass, with the presence of additional thoracic adenopathies helping to suggest the correct diagnosis. ${ }^{1}$ This was noted only in our first case. CT is very useful for assessing the invasion of adjacent mediastinal and thoracic structures, ${ }^{1}$ although NMR has been used in recent years since the images can better distinguish the thymic tumor from neighboring structures. Thymic tumors typically give off a homogeneous low-intensity signal, similar to muscle, in sequence $\mathrm{T} 1$, and a mixed or a high-intensity signal, similar to or greater than fat, in sequence T2.5

Fine-needle aspiration has been used for the differential diagnosis of thymic lesions, especially when thymomas are suspected. ${ }^{6}$ The cytologic state most suggestive of lymphoma is that in which lymphoid cells predominate in the aspirate; the 2 diseases that must be considered in the differential diagnosis are thymoma and thymic hyperplasia. ${ }^{6}$

Despite all these diagnostic techniques it is difficult to obtain a definitive preoperative diagnosis in most thymic lesions. Therefore, surgeons must often resort to an open biopsy, as was true in our cases. The approach of choice is an anterior mediastinotomy. However, as the histologic study done for the intraoperative biopsy 
(freezing techniques) has a lower diagnostic yield than definitive histologic tests (eg, inclusion in paraffin, immunohistochemical techniques), the problem arises when we have a dubious diagnosis with thymoma in patients with surgically resectable disease, in which case there is doubt as to whether to perform thymectomy or not. Although some authors have performed resection of the lymphoma in Hodgkin disease, ${ }^{7}$ most accept that biopsy is enough to confirm the lymphoma and its variant, because treatment is chemotherapy and radiotherapy. In our series the 2 patients who had removal of the thymus (cases 2 and 3 ) had major postoperative complications, and surgery did not improve the prognosis.

Hodgkin disease is the most common type of thymic lymphoma, ${ }^{1,4}$ unlike lymphomas of the rest of the organism, in which Hodgkin disease accounts for just $20 \%$ to $25 \%$ of all cases. In most thymic Hodgkin disease the most common histologic type is nodular sclerosis, ${ }^{1,4}$ as the other types typically affect the lymph nodes except the thymus. ${ }^{1,3}$ On histologic study, nodular sclerosis Hodgkin disease is characterized by a microscopic nodularity, composed of lymphoid cells interspersed with a marked inflammatory cell reaction and separated by wide fibrous bands. Identification of Reed-Sternberg cells confirms the diagnosis. ${ }^{1}$ These lymphomas that primarily affect the thymus may be confined by the thymic capsule or may be locally invasive. ${ }^{1}$

Because Hodgkin disease spreads through the adjacent lymph node groups, anatomic staging is a good predictor of survival. Classically, the Ann Arbor system has been used. This has now been updated (Cotswold Ann Arbor modified staging system). ${ }^{2}$ Three of our patients had stage I disease and the other had stage II. The stages in this system can be subclassified into 3 categories: A (no generalized symptoms); B (well-defined generalized symptoms); or E (extralymphatic involvement).

Treatment of Hodgkin disease has varied greatly in recent decades, and the Cotswold staging system currently enables us to determine which patients are going to benefit from radiotherapy and/or chemotherapy. In stages I or II with nonbulky Hodgkin disease, radiotherapy alone is adequate. However, patients with bulky Hodgkin disease or those who require extensive radiation of normal tissue should be given chemotherapy followed by radiotherapy, as occurred in our cases. In patients with stages III and IV, treatment is chemotherapy occasionally combined with radiotherapy. ${ }^{2}$ Most authors recommend chemotherapy followed by radiotherapy for patients with a large mediastinal mass. ${ }^{2}$ The currently most accepted course of chemotherapy is ABVD (Adriamycin [doxorubicin], bleomycin, vincristine, and dacarbazine); if it is not effective or the patient has active residual disease, it is then complemented with C-MOPP (cyclophosphamide, vincristine, procarbazine, prednisone), as occurred in our third case.

Sometimes a residual mass remains after treatment, and determining whether it is fibrosis or a viable tumor is difficult, especially in the first few months. ${ }^{5}$ Mediastinal ultrasound, CT, and NMR have been used to assess these residual tumors. However, positron emission tomography and gammagraphy with gallium 67 currently seem to be the most useful for determining whether this residual area harbors tumor activity or merely fibrosis. ${ }^{8}$

In stages I and II the cure rates are higher than $90 \%$ with radiotherapy alone. Stage III has a survival of $65 \%$ to $85 \%$ with chemotherapy and radiotherapy. In stage IV these figures drop to $50 \%$ to $60 \% .^{1,2}$ The main factors for a poor prognosis as defined for Hodgkin disease are large tumor size, direct invasion of the lung or adjacent tissues, advanced stage, presence of constitutional symptoms (category B), and age older than 50 to 60 years. ${ }^{2,3}$

Approximately $50 \%$ of the patients have recurrence of the disease, generally in adjacent lymphatic groups and potentially curable with aggressive chemotherapy. ${ }^{1,2,4}$ It is necessary to wait 2 decades to consider a patient totally cured with practically no possibility of recurrence, which is why we can regard only 1 of our 4 patients as cured.

\section{References}

1. Strollo DC, Rosado de Christenson ML. Tumors of the thymus. J Thorac Imaging. 1999;14:152-71.

2. Strollo DC, Rosado de Christenson ML, Jett JR. Primary mediastinal tumors. Part II. Tumors of the middle and posterior mediastinum. Chest. 1997;112:1344-57.

3. Kennedy BJ, Fremgen AM, Menck HR. The National Cancer Data Base report on Hodgkin's disease for 1985-1989 and 1990-1994. Cancer. 1998;83:1041-7.

4. Keller AR, Castleman B. Hodgkin's disease of the thymus gland. Cancer. 1974;33:1615-23.

5. Rahmouni A, Tempany C, Jones R, Mann R, Yang A, Zerhouni E. Lymphoma: monitoring tumor size and signal intensity with MR imaging. Radiology. 1993;188:445-51.

6. Shin HJ, Katz RL. Thymic neoplasia represented by fine needle aspiration biopsy by anterior mediastinal masses: a practical approach to the differential diagnosis. Acta Cytol. 1998;42:855-64.

7. Bacha EA, Chapelier AAR, Macchiarini P, Fadel E, Dartevelle PG Surgery for invasive primary mediastinal tumors. Ann Thorac Surg. 1998;66:234-9.

8. Kaplan WD, Jochelson MS, Herman TS, Nadler LM, Stomper PC, Takvorian T, et al. Gallium-67 imaging: a predictor of residual tumor viability and clinical outcome in patients with diffuse large-cell lymphoma. J Clin Oncol. 1990;8:1966-70. 